Como su nombre lo indica, El Urbanismo Inka del Cusco. Nuevas Aportaciones brinda un recuento de las investigaciones realizadas, y sintetiza los últimos aportes sobre las construcciones y la conformación física del Cusco inka. La dirección científica y edición estuvo a cargo de cuatro profesionales: los arquitectos Crayla Alfaro, José Beltrán-Caballero y Ricardo Mar, y el arqueólogo Ramiro Matos.

Sin desmerecer otros trabajos reconstructivos como los llevados a cabo por el Museo de la Nación (Lima), Kubler, Chávez Ballón, Paredes, Bauer, Farrington y el propio Agurto, este es sin duda el más completo e integral intento de aproximación a la reconstrucción física de la ciudad inka del Cusco.

Cabe mencionar que la columna base del libro tiene como antecedente los trabajos reconstructivos que los arquitectos José Beltrán-Caballero (colombiano) y Ricardo Mar (español) llevaron a cabo sobre Sacsayhuamán y los recursos hídricos que posee el territorio cusqueño, así como la tesis doctoral de Beltrán-Caballero sobre la forma urbana del Cusco, cuyo director justamente fue Mar, y se realizó con el apoyo del arqueólogo Ramiro Matos (otro de los editores del libro), el Instituto Smithsoniano y la Universidad de Tarragona. El trabajo de los arquitectos tuvo como colofón un modelo 3D interactivo del Cusco inka. En el presente libro se constata el aporte de ambos arquitectos en el número de páginas en las que participan ambos como autores colaboradores.

La presentación de esta publicación da buena cuenta de la positiva visión con que el Gobierno de la ciudad ha asumido su liderazgo y está aportando a la construcción de valiosas estrategias de gestión del centro histórico del Cusco. La perspectiva institucional que la gerente del centro histórico de la Municipalidad del Cusco, la Arq. Crayla Alfaro, comparte en este breve texto, ayuda a comprender -y valorar- no solo la apuesta por contribuir al buen vivir en una ciudad histórica como Cusco, sino a la comprensión de la especificidad urbana de su centro histórico: la apuesta conmemorativa municipal de creación del Centro de Documentación de la Gerencia de la Ciudad Histórica-siguiendo referentes como La Habana Vieja-, la formulación del Plan Maestro del Centro Histórico como instrumento de gestión de enfoque estratégico y gerencial, y la definición y prio-

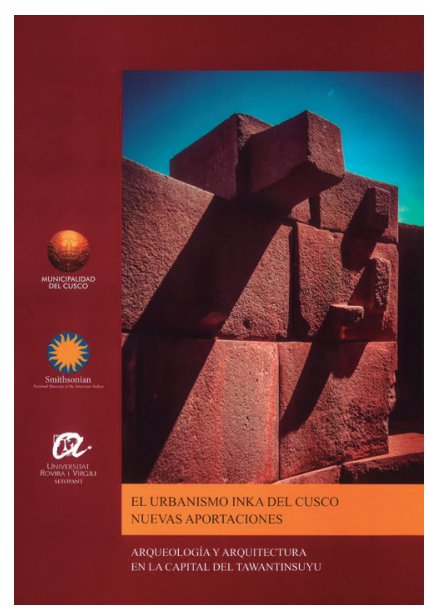

\section{EL URBANISMO INKA DEL CUSCO. NUEVAS APORTACIONES}

CRAYLA ALFARO, JOSÉ BELTRÁN-CABALLERO, RICARDO MAR Y RAMIRO MATOS (EDICIÓN CIENTÍFICA] MUNICIPALIDAD DEL CUSCO - NATIONAL MUSEUM OF AMERICAN INDIAN - UNIVERSITAT ROVIRA I VIRGILI, CUSCO-PERÚ, 2014.

RESEÑA DE CARLOS ENRIQUE GUZMÁN rización de cuatro líneas de acción y sus correspondientes estrategias para contribuir al logro de tan nobles fines.

Este libro se desarrolla en seis capítulos. En el primero se hace un recuento de la superposición de construcciones urbanas que se han ido sucediendo sobre las de factura inka, desde el Virreinato hasta la actualidad, y se plantea la posibilidad de hacer una reconstrucción lo más fidedigna posible del Cusco primigenio.

En el segundo capítulo se exploran los restos visibles de terrazas, estructuras y huacas que rodeaban el núcleo central de la llamada "ciudad Puma", recurriendo a fotos aéreas antiguas y vestigios actuales. Se incluye al inicio un notable plano de síntesis, donde sobre una foto aérea se delinean los restos inkas de edificios, terrazas, caminos y huacas, mientras que en el siguiente capítulo se presentan los caminos de este entorno.

El cuarto es el más voluminoso de los capítulos. Cierra magistralmente el tema de la reconstrucción física del Cusco inkaico, y recoge toda la información sobre muros, edificaciones, rocas sagradas $y$ andenes presentes en el mismo casco urbano. A partir de dicha información, una vez sintetizada en plano, se propone una reconstrucción hipotética del casco inka, la cual se completa con la reconstrucción 3D del templo solar del Hanan Cusco, construido sobre el apu Sacsayhuamán, donde destacan las murallas escalonadas en zigzag y las tres torres mencionadas en las crónicas.

Los dos últimos capítulos (quinto y sexto) complementan lo presentado en los precedentes. Recurren a las narraciones de los cronistas respecto a las fiestas celebradas en el Cusco, pero se enfocan en analizar el uso del espacio y los posibles límites de la capital inka. Además, es un lujo contar en estas secciones con la participación de dos especialistas renombrados, Ariadna Baulenas (colaboradora científica del Seminario de Topografía Antigua de la Universitat Rovira i Virgili y asesora del Museu de les Cultures del Món de Barcelona) y Donato Amado (Ministerio de Cultura, Región Cusco).

Lo particular de esta publicación es la notoria intención de mostrar imágenes y fotos de los restos, así como reconstrucciones hipotéticas del Cusco inka, quizá porque del total de autores de los capítulos, tres son arquitectos que trabajan interdependientemente con diversos especialistas.

Ello obliga a reflexionar respecto de una consideración que debe estar presente en este tipo de trabajos: la participación multidisciplinaria. No obstante, este esfuerzo va más allá de dicha consideración, y se instala en la dinámica del trabajo colaborativo interinstitucional, ya que tanto la Municipalidad del Cusco, como el National Museum of American Indian y la Universitat Rovira i Virgili han cooperado intensamente, en la medida de sus posibilidades, para materializar un aporte académico maduro e innovador. Sin duda, son dos singulares fortalezas que invitan a sumergirse en sus interesantes páginas... 